\title{
Derivative Trading and Spot Market Volatility: Evidence from Indian Market
}

\author{
${ }^{1}$ Dr. Dhanya Alex, ${ }^{2}$ Dr. Roshna Varghese \\ ${ }^{1}$ Associate Professor, FISAT Business School, Mookkannoor, Angamaly, Kochi \\ Email: dhanyaalex007@gmail.com \\ ${ }^{2}$ Assistant Professor, Rajagiri College of Social Sciences, Rajagiri Valley Campus \\ P O, Kakkanad, Kochi, Kerala - 682039 \\ Email: roshna@rajagiri.edu; roshnavarghese@gmail.com
}

\begin{abstract}
The present study tries to estimate the effect of introduction of individual stock derivatives on the underlying stock volatility in Indian stock market. To estimate the effect of introduction of derivatives on stock market, GARCH family models which are known for their ability to model volatility. The return series of the ten companies were tested using methods like, unit root test and descriptive statistics to confirm that GARCH models could be used. Using these models, the asymmetric nature of stock returns and the volatility of stock returns on the introduction of derivatives are checked. The results reveal that the introduction of derivatives has decreased the volatility of the underlying stock returns. It was also found that most of the stock returns show asymmetric behaviour.
\end{abstract}

Key words: Derivatives, GARCH, Stock volatility

\section{INTRODUCTION}

The modelling of asset returns volatility remains as an active topic of analytic and empirical interest. It provides substantial information on the risk patterns involved in investment and transaction processes. Several empirical researches have been carried out to understand the effect of introduction of derivatives on the volatility of the spot markets and also to explore its role in stabilising or destabilising the cash markets. It is widely known in finance research that stock return volatility is highly persistent, especially in the developing markets. High levels of price volatility exhibited by the stock markets emphasizes on the need to examine the dynamics of volatility, to reduce the unpredictable outcomes. The volatility behaviour of the stock market has become further complicated with the introduction of derivatives in the equity markets in the major world markets. The derivative instruments were launched with the objectives to transfer risk and to increase liquidity, thereby ensuring better market efficiency. Along with this, derivatives open new avenues for hedging and speculation, which further complicates the volatility behaviour of the stock markets.

Cox (1976) Figlewski (1981) Stein, (1987) argued that the introduction of futures trading increased the spot market volatility which resulted in destabilizing the market. These researchers perceived derivative market as a market for speculators. They suggested that derivative market encouraged the participation of speculative traders with very little or no cash or shares which resulted in high degree of leverage in the market, thereby increasing the risk. This has also resulted in lowering the quality of information in the market. Chatrath, Ramchander and Song, (1995) commented that uninformed traders could play a destabilising role in cash markets.

Powers, (1970) Schwarz and Laatsch, (1991) found that the introduction of futures actually reduces the spot market volatility which will stabilise the market. All these debates clearly point out that volatility is undesirable. Questions pertaining to the impact of derivative trading on cash market volatility have been empirically addressed in two ways: by comparing cash market volatilities during the pre-and postfutures/ options trading eras and second, by evaluating the impact of options and futures trading (generally proxied by trading volume) on the behaviour of cash markets. The literature is, however, inconclusive on whether introduction of derivative products lead to an increase or decrease in the spot 
market volatility. To capture the volatility in financial time-series, several models of conditional volatility have been proposed. An outstanding class of model was first introduced by Engle (1982) which was known as the ARCH (autoregressive conditional heteroscedasticity) model. This model was later generalized by Bollerslev (1986) to GARCH (generalized ARCH) model by including the lags of conditional variance itself. In these models, one very common finding in the financial asset is that shocks to volatility are often highly persistent.

The history of derivative trading in India can be traced way back to the $19^{\text {th }}$ century. In the initial days it was mainly in the form of commodity forwards. In 1875, Bombay cotton trade association started trading commodity futures. During the early 1900s, India had one of the largest futures industry. However in 1952, the government banned such contracts and the derivative trading shifted to informal forwards. The ban on commodity derivatives was lifted in the early 2000s. The derivatives trading on the National Stock Exchange (NSE) commenced on June 12, 2000 with futures trading on S\&P CNX Nifty Index. It was followed by trading in index options and options on individual securities which started on June 4, 2001 and July 2, 2001 respectively. Single stock futures were launched on November 9, 2001. Since then, the futures and options (F\&O) segment has been growing continuously in terms of new products, contracts, traded volume and value. At present, the NSE has established itself as the market leader in this segment in India, with more than 99.5 percent market share. Indian market is one of the largest derivative markets in the world. The growth of Indian derivative market is shown in the following figure. (Fig.1)

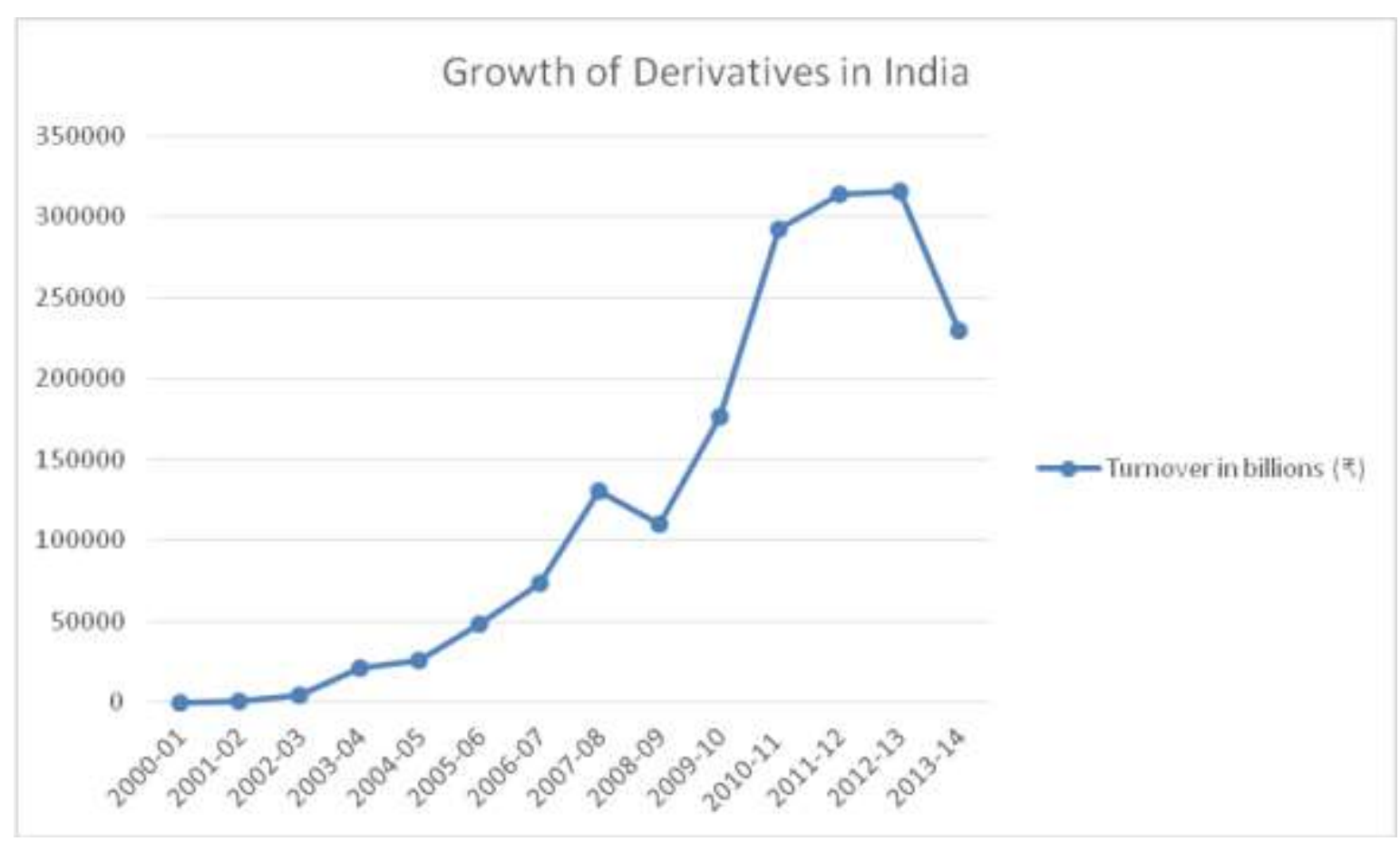

Figure 1: Growth of Derivatives in India (Source: Compiled from NSE and BSE Websites)

Earlier studies have used two different methods to understand the impact of derivative trading on cash market volatility. The first method is by comparing cash market volatilities during the pre-and postfutures/ options trading eras and second, by evaluating the impact of options and futures trading (generally proxied by trading volume) on the behaviour of cash markets. However, the previous studies done on the volatility effects of derivatives trading in India had given inconclusive results which suggest the need for a robust examination of the impact of derivatives on market volatility. Against this backdrop, it is important to empirically examine the impact of derivatives on the stock market. The present study tries to estimate the effect of introduction of individual stock derivatives on the underlying stock volatility in Indian stock market by considering the stock derivatives introduced in the year 2010. This paper is organised as follows: following the introduction, the section 2 presents literature review, followed by section 3 on research methodology. The section 4 provides results and discussion on key findings and section 5 discusses the concluding remarks. 


\section{Dr. Dhanya Alex, Dr. Roshna Varghese \\ Derivative Trading and Spot Market Volatility: Evidence from Indian Market}

\section{LITERATURE REVIEW}

Prior studies have been conducted in India and abroad to study the effect of derivatives on the underlying asset's price volatility. Initial researches concentrated on the commodity futures and their effect on the underlying commodities. With the introduction of index futures, researchers were interested in estimating the effect of these derivatives on the underlying indices. After the introduction of individual stock derivatives, studies were done to identify their effect on the underlying assets. The results of the studies weren't similar as they were done in different markets at different time periods. Researchers used different approaches to understand the issues and the latest approach is the use of GARCH family techniques to study the volatility of stock returns. Cox (1976) studied price series of six commodities and concluded that the future trading has increased the amount of information known to the traders. He also concluded that the future trading has increased the efficiency of the underlying market which is a commodity market in this case. Antoniou and Holmes (1993) in their study based on the markets in United Kingdom found out that the introduction of index derivatives increased the spot price volatility on a daily basis. The reasons identified by them were the increased information in the market and the expansion of information route in the markets due to futures trading. Dennis et.al., (1999) conducted a study in the Australian market and concluded that most of the individual stock futures do not have any effect on the respective underlying stocks. But very few stocks showed change in volatility either increasing or decreasing. The study done on Taiwan Index futures by Min-Hsien and Cheng-Yu (2002) found that the introduction of TAIEX futures has increased the spot price volatility. They also found out that the asymmetric nature of the spot market has increased, as large numbers of uninformed noninstitutional members overreacted to the bad news than to the good news. Bologna and Cvallo (2002) found out that the introduction of Fib30 has reduced the unconditional volatility in the post-futures period and also the effect was found out to be immediate. The results also suggested that the introduction of futures has increased the efficiency of the market by reducing the volatility.

There are a number of studies done in Indian markets to understand the effect of derivative trading on spot market volatility. Thenmozhi (2002) had carried out a study on NSE-50 Index Futures Contracts. She used regression analysis and found out that introduction of index futures has decreased the volatility of spot index returns. The main reasons identified were the greater information flow in the post futures period and the shift of speculators from spot market to the futures market due to low transaction and marginal costs.

Bandivadekar and Gosh (1993) conducted a study using ARCH and GARCH techniques on the futures of S\&P CNX Nifty and BSE Sensex. They found out that in case of Nifty the volatility of underlying stock has decreased significantly, but in case of Sensex, the change was not significant as the amount trade of Sensex futures were considerably low. When Nath (1993) studied the impact of individual stock futures on the underlying stocks, it was the first of its kind study in the Indian market. He used the GARCH family models to understand the effect. He found out that the introduction of individual derivatives has decreased the volatility of most of the stocks under study. When compared with the earlier Indian studies he used a longer time period and has also taken into account the cyclical trends in the market. Results of the Indian studies given above were almost similar. They all said that the introduction of derivatives reduced the volatility of the underlying in the post derivative period. But Shenbagaraman (1993) came out with a contradicting result that the introduction of derivatives did not have any significant effect on the spot market. She also used GRCH family methods to identify the impact of derivatives introduction. Nair (2011) conducted a study on the impact of derivative trading on the volatility of the underlying assets in Indian stock markets. He studied the asymmetric nature of stock returns using GJR GARCH method. He found out that stocks got an asymmetric nature and that the introduction of derivatives has decreased the volatility of the underlying stocks. He also concluded that the introduction of derivatives has increased the effect of new information on the spot market.

The regulatory frame work for derivative trading is based on L.C Gupta Committee report and J.R. Varma Committee. The frame work in India is mostly consistent with regulations of international organization of securities commission. Securities Exchange Board of India (SEBI) is the primary regulatory body. Some of the regulations are also done by Reserve Bank of India and the financial ministry.

\section{RESEARCH METHODS}

The study was done with an objective to understand the change in spot market volatility with the introduction of stock derivatives. Minor objective of the study is to identify the asymmetric nature in returns.. The present study tries to estimate the effect of derivatives on all the stocks, for which derivatives were introduced in the year 2010 in the National Stock exchange (NSE). Here the researchers have considered only those derivatives which are still on trade and a minimum of 500 days trading data prior to the introduction of derivatives is available. Ten companies were found to be satisfying all the three above said criteria. Closing prices of these companies' stock for a total of 1000 days, 500 days before and after the commencement of derivatives was collected. To incorporate the effect of market 
wide factors, the closing price of S\&P CNX Nifty for the respective 1000 days is also collected. All these data are collected from NSE website. From the close prices collected, the returns are calculated using the following formula,

$$
R_{t}=\ln \left(P_{t} / P_{t-1}\right)
$$

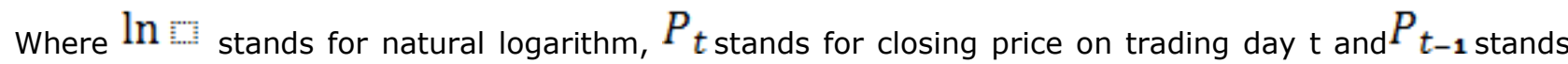
for closing price on the previous trading day. During the calculations the data is used mainly in three forms, they are pre derivatives period, post derivative period and full period. Logarithmic return is preferred over percentage return as in case of percentage return negative values couldn't be below 100 while on positive side there was no limit.

The logarithmic returns were calculated using Microsoft Excel whereas the rest of the calculations were done using E-Views 7.2.

Robert F Engle in 1982 introduced a new model called Auto-Regressive Conditional Heteroscedasticity or $\mathrm{ARCH}$. It was the first model that provided a systematic structure or framework to model volatility. The main features of this model are, it is a model with an autoregressive or regression on itself and the conditional variance had time variation built into it. Another feature of ARCH models is that it could explain the volatility clustering of financial asset returns. Volatility clustering means large changes in asset returns will be followed by large returns and small changes in asset returns will be followed by small changes, in both the directions. The ARCH model consists of the mean equation and the conditional variance equation. In the original formulation of $\mathrm{ARCH}$ model the variance is calculated as a moving average of past error terms which is given as,

$$
\boldsymbol{h}_{t}=\omega+\sum_{i=\mathbf{1}}^{p} a_{i} \varepsilon_{t-1}^{2}
$$

Where $\omega$ is a constant, $a_{i}$ is a constant determined from the empirical data, both $\omega$ and $a_{i \text { are non- }}$ negative and $\varepsilon$ is the error term which is given as follows, $\varepsilon_{t}=\sqrt{h_{t}} Z_{t}$ Where ${ }^{Z}$ terms are independent standard normal variables.

In 1986, Tim Bollerslev introduced a generalised form of ARCH called GARCH or General AutoRegressive Conditional Heteroscedasticity. This model is also a weighted average of past squared residuals, but this has declining weights which will never become zero, also all past errors will contribute to forecast volatility. The most simple form is $\operatorname{GARCH}(1,1)$, for which the conditional variance is,

$$
\boldsymbol{h}_{t}=\omega+a_{i} \varepsilon_{t-1}^{2}+\beta_{i} h_{t-1}
$$

Here the constants $\omega, a$ and $\beta$ are greater than zero. The second last term of the equation represents the squared error terms and the last term represents the lagged conditional variance.

One of the drawbacks of the standard $\mathrm{GARCH}$ model is that it assumes response of volatility to information is symmetric. But in reality the return series show asymmetry, that is, the effect of 'bad' news is greater than that of the effect of 'good' news. Thus, the use of standard GARCH models in these cases may lead to misrepresentation of relationships and the inferences or interpretations will be misleading. This led to the development of new models which could measure the asymmetry in time series. One of the major asymmetric models is GJR-GARCH model. It was developed by Glosten, Jagannathan and Runkle in 1993. The conditional equation of this model is,

$$
\boldsymbol{h}_{t}=\omega+a_{i} \varepsilon_{t-1}^{2}+\beta_{i} h_{t-1}+\gamma_{i} s_{t-1}^{-} \varepsilon_{t-1}^{2}
$$

Where $S_{t-1}^{-}=1$ if $\varepsilon_{t-1}<0$ and $S_{t-1}^{-}=0$ other wise. The term $S_{t-1}^{-}$is generally known as leverage parameter. So it's the apt model to be used in our study or analysis 
To understand the changes in volatility, a dummy variable is included in the conditional variance equation. The dummy variable will take the value 0 prior to the introduction of derivatives and value 1 after the introduction of derivatives. After inclusion of this the conditional equation of standard GARCH model is,

$$
\boldsymbol{h}_{t}=\omega+a_{i} \varepsilon_{t-1}^{2}+\beta_{i} h_{t-1}+\gamma D
$$

The conditional variance of GJR GARCH will also change. The new formula is given as,

$$
\boldsymbol{h}_{t}=\omega+a_{i} \varepsilon_{t-1}^{2}+\beta_{i} h_{t-1}+\gamma_{i} s_{t-1}^{-} \varepsilon_{t-1}^{2}+\gamma D
$$

While considering the effect of derivatives on stock market volatility, it is also important to consider the general changes in the market or the macroeconomic factors. For this, the return of nifty is included in the mean equations of the standard GARCH and GJR GARCH. The mean equation is given as,

$$
R_{t}=c+\beta * R_{\text {nifty }}+\varepsilon_{t}
$$

Where $R_{\text {nifty }}$ is the return of nity and $\varepsilon_{t}$ is the white noise.

The data to be used with the GARCH model should be free of trends or should be stationary. In order to check for trends in the series, unit root test is performed. If some trend is found it could be removed through first differencing or through time trend regression. In the study we use Dickey-Fuller test and Phillips-Perron test for unit root testing. Hypothesis used for this are,

Null Hypothesis $\left(\mathrm{H}_{0}\right)$ : Series has a unit root.

Alternate Hypothesis $\left(\mathrm{H}_{1}\right)$ : Series is stationary.

The series is also tested using LM ARCH test. This test is done to identify the ARCH effect in the series. Hypothesis used for this test are,

Null Hypothesis $\left(\mathrm{H}_{0}\right)$ : There is no ARCH effect.

Alternate Hypothesis $\left(H_{1}\right)$ : There is ARCH effect.

\section{ANALYSIS AND EMPIRICAL RESULTS \\ a. Unit Root Test}

Unit root test is done for the return series at level variables using both Dickey-Fuller (ADF) test and Phillips-Perron (PP) test. Lag length is selected based on Schwarz Info Criterion (SIC), and lag length is found to be 21 . The table (Table 1 ) presents data on with intercept, with intercept and trend and without intercept and trend.

Table 1: Results of Unit Root Test (Source: Authors' computation using E- views)

\begin{tabular}{|c|c|c|c|c|c|c|}
\hline \multirow{2}{*}{ Stock } & \multicolumn{3}{|c|}{ Augmented Dickey- Fuller test } & \multicolumn{3}{c|}{ Phillips-Perron Test } \\
\cline { 2 - 7 } & $\begin{array}{c}\text { With } \\
\text { Intercept } \\
(-3.43)\end{array}$ & $\begin{array}{c}\text { With } \\
\text { intercept } \\
\text { and trend } \\
3.96)\end{array}$ & $\begin{array}{c}\text { Without } \\
\text { intercept } \\
\text { and trend } \\
(-2.58)\end{array}$ & $\begin{array}{c}\text { With } \\
\text { Intercept } \\
(-3.43)\end{array}$ & $\begin{array}{c}\text { With } \\
\text { intercept } \\
\text { and trend } \\
3.96)\end{array}$ & $\begin{array}{c}\text { Without } \\
\text { intercept } \\
\text { and trend } \\
(-2.58)\end{array}$ \\
\hline $\begin{array}{c}\text { Adani } \\
\text { Enterprises } \\
\text { Limited }\end{array}$ & -28.15215 & -28.13921 & -28.15575 & -28.28822 & -28.27564 & -28.29400 \\
\hline $\begin{array}{c}\text { Apollo Tyres } \\
\text { Ltd }\end{array}$ & -29.74327 & -29.74558 & -29.74859 & -29.73337 & -29.72794 & -29.74250 \\
\hline $\begin{array}{c}\text { Exide } \\
\text { Industries Ltd }\end{array}$ & -32.51020 & -32.49902 & -32.51507 & -32.50465 & -32.49360 & -32.50931 \\
\hline $\begin{array}{c}\text { Godrej } \\
\text { Industries Ltd }\end{array}$ & -30.00500 & -30.04834 & -30.01626 & -30.01106 & -30.04497 & -30.02275 \\
\hline $\begin{array}{c}\text { Hexaware } \\
\text { Technologies } \\
\text { Ltd }\end{array}$ & -32.55469 & -32.56125 & -32.56517 & -32.63327 & -32.63951 & -32.64197 \\
\hline
\end{tabular}


Dr. Dhanya Alex, Dr. Roshna Varghese

Derivative Trading and Spot Market Volatility: Evidence from Indian Market

\begin{tabular}{|c|c|c|c|c|c|c|}
$\begin{array}{c}\text { Indraprastha } \\
\text { Gas Ltd }\end{array}$ & -32.32824 & -32.38008 & -32.31221 & -32.51426 & -32.68961 & -32.45567 \\
\hline $\begin{array}{c}\text { Jain Irrigation } \\
\text { Systems }\end{array}$ & -31.28017 & -31.28457 & -31.27036 & -31.28081 & -31.28477 & -31.27161 \\
\hline $\begin{array}{c}\text { Mcleod Russel } \\
\text { India Ltd }\end{array}$ & -30.71959 & -30.71751 & -30.71293 & -30.71959 & -30.71751 & -30.71293 \\
\hline NMDC Ltd & -27.30267 & -27.29817 & -27.31583 & -27.35974 & -27.35128 & -27.37297 \\
\hline $\begin{array}{c}\text { Shriram } \\
\text { Transport Fin } \\
\text { Co }\end{array}$ & -30.18953 & -30.18578 & -30.18336 & -30.23013 & -30.22129 & -30.22500 \\
\hline
\end{tabular}

The return series is tested for presence of unit root at level variable. The values given in brackets in the heading column are the critical values at $1 \%$ level of significance. As the absolute values of the results are greater than the critical values, we can confirm that the null hypothesis is rejected. Hence the alternate hypothesis that the series is stationary is accepted. Thus using the unit root test it is proved that the series is stationary or data is free from trends. Hence data could be used for modelling with GARCH.

Table 2: Summary Statistics for Pre Derivative Period (Source: Authors' computation)

\begin{tabular}{|c|c|c|c|c|}
\hline Name of the Stock & Skewness & Kurtosis & Jarque-Bera & ARCH Test \\
\hline Adani Enterprises Limited & -5.971783 & 87.987140 & 153447.200 & 0.17 \\
\hline Apollo Tyres Ltd & 0.608704 & 6.575570 & 297.225 & 24.75 \\
\hline Exide Industries Ltd & 0.257883 & 4.083841 & 30.015 & 65.25 \\
\hline Godrej Industries Ltd & 0.395347 & 5.090797 & 104.096 & 38 \\
\hline Hexaware Technologies Ltd & 2.696324 & 32.392080 & 18603.650 & 1 \\
\hline Indraprastha Gas Ltd & 0.335557 & 7.625452 & 455.108 & 99.09 \\
\hline Jain Irrigation Systems & -0.023566 & 5.458958 & 126.015 & 64.91 \\
\hline Mcleod Russel India Ltd & 0.412117 & 4.966420 & 94.712 & 12.01 \\
\hline NMDC Ltd & 1.348030 & 8.602672 & 805.389 & 34.88 \\
\hline Shriram Transport Fin Co & 0.051075 & 10.198480 & 1079.763 & 14.82 \\
\hline
\end{tabular}

The results indicate that, for all the scripts in their pre derivatives period skewness is non zero and the kurtosis is in excess of three. Further, the Jarque-Bera (JB) test indicates that the assumption of normality is violated in the pre derivatives period. Further in most of the cases, ARCH test values are greater than the critical values at $1 \%$ level, so the hypothesis that there is no ARCH effect is rejected.

Table 3: Summary Statistics for Post Derivative Period (Source: Authors' computation)

\begin{tabular}{|c|c|c|c|c|}
\hline $\begin{array}{c}\text { Name of the } \\
\text { Stock }\end{array}$ & Skewness & Kurtosis & Jarque-Bera & ARCH Test \\
\hline $\begin{array}{c}\text { Adani Enterprises } \\
\text { Limited }\end{array}$ & -1.575358 & 16.984990 & 4281.3920 & 16.91 \\
\hline Apollo Tyres Ltd & 0.193933 & 4.291068 & 37.860330 & 29.87 \\
\hline $\begin{array}{c}\text { Exide Industries } \\
\text { Ltd }\end{array}$ & -0.462067 & 5.580386 & 156.508700 & 4.59 \\
\hline
\end{tabular}


Dr. Dhanya Alex, Dr. Roshna Varghese

Derivative Trading and Spot Market Volatility: Evidence from Indian Market

\begin{tabular}{|c|c|c|c|c|}
\hline $\begin{array}{c}\text { Godrej Industries } \\
\text { Ltd }\end{array}$ & 0.037816 & 3.806154 & 13.658440 & 2.7 \\
\hline $\begin{array}{c}\text { Hexaware } \\
\text { Technologies Ltd }\end{array}$ & -10.592560 & 189.934200 & 737358.100 & 0.03 \\
\hline $\begin{array}{c}\text { Indraprastha Gas } \\
\text { Ltd }\end{array}$ & -4.870594 & 104.770900 & 217754.400 & 0.44 \\
\hline $\begin{array}{c}\text { Jain Irrigation } \\
\text { Systems }\end{array}$ & -17.132890 & 350.608300 & 2541785.000 & 0.034 \\
\hline $\begin{array}{c}\text { Mcleod Russel } \\
\text { India Ltd }\end{array}$ & 0.010831 & 3.393678 & 3.238574 & 21.38 \\
\hline $\begin{array}{c}\text { NMDC Ltd } \\
\text { Shriram Transport } \\
\text { Fin Co }\end{array}$ & -0.091716 & 3.917554 & 18.240660 & 28.63 \\
\hline \begin{tabular}{c} 
Shram \\
\hline
\end{tabular} & 4.309131 & 36.051030 & 27.67 \\
\hline
\end{tabular}

The results indicate that, for all the scripts in their post derivatives period skewness is non-zero and the kurtosis is in excess of three. Further, the JB test indicates that the assumption of normality is violated in the post derivatives period. Further in most of the cases $\mathrm{ARCH}$ test values are greater than the critical values at $1 \%$ level, so the hypothesis that there is no $\mathrm{ARCH}$ effect is rejected.

Table 4: Summary Statistics for Full Period (Source: Authors' computation)

\begin{tabular}{|c|c|c|c|c|}
\hline Name of the Stock & Skewness & Kurtosis & Jarque-Bera & ARCH Test \\
\hline Adani Enterprises Limited & -5.600045 & 96.645690 & 370623.200000 & 0.08 \\
\hline Apollo Tyres Ltd & 0.470506 & 6.128051 & 444.591900 & 48.46 \\
\hline Exide Industries Ltd & 0.066636 & 4.826720 & 139.777800 & 85.61 \\
\hline Godrej Industries Ltd & 0.344799 & 6.533070 & 539.922000 & 113.4 \\
\hline Hexaware Technologies Ltd & -3.617964 & 105.802000 & 442525.300000 & 0.05 \\
\hline Indraprastha Gas Ltd & -3.206844 & 81.087830 & 255785.200000 & 1.64 \\
\hline Jain Irrigation Systems & -18.892830 & 503.515500 & 10497648.000000 & 0.023 \\
\hline Mcleod Russel India Ltd & 0.450328 & 6.236121 & 470.152300 & 60.23 \\
\hline NMDC Ltd & 1.238368 & 10.195350 & 2412.802000 & 86.34 \\
\hline Shriram Transport Fin Co & 0.060476 & 7.401833 & 807.948500 & 26.65 \\
\hline
\end{tabular}

The results indicate that, for all the scripts in their full period skewness is non-zero and the kurtosis is in excess of three. Further, the JB test indicates that the assumption of normality is violated in the whole period. Further in most of the cases $\mathrm{ARCH}$ test values are greater than the critical values at $1 \%$ level the hypothesis that there is no ARCH effect is rejected.

b. Test for Asymmetry

GJR GARCH $(1,1)$ used to check the asymmetric nature of the stock returns. For this data for the entire period is used. Following table shows returns and their significance values. 
Dr. Dhanya Alex, Dr. Roshna Varghese

Derivative Trading and Spot Market Volatility: Evidence from Indian Market

Table 5: Test for Asymmetry (Source: Authors' computation)

\begin{tabular}{|l|c|c|c|c|}
\hline Name of the Stock & Constant & ARCH & GARCH & Leverage \\
\hline \multirow{2}{*}{ Adani Enterprises Limited } & $\begin{array}{c}0.003387 \\
(64.0366)\end{array}$ & $\begin{array}{c}0.159312 \\
(2.664867)\end{array}$ & $\begin{array}{c}-0.024564 \\
(-27.25381)\end{array}$ & $\begin{array}{c}0.131302 \\
(1.429748)\end{array}$ \\
\hline \multirow{2}{*}{ Apollo Tyres Ltd } & $\begin{array}{c}0.000145 \\
(4.30695)\end{array}$ & $\begin{array}{c}0.020495 \\
(1.545564)\end{array}$ & $\begin{array}{c}0.79923 \\
(21.7316)\end{array}$ & $\begin{array}{c}1.23 e-01 \\
(3.704372)\end{array}$ \\
\hline \multirow{2}{*}{ Exide Industries Ltd } & $5.92 \mathrm{e}-05$ & 0.074676 & 0.818832 & 0.052853 \\
& $(3.244907)$ & $(3.09493)$ & $(21.56001)$ & $(1.622755)$ \\
\hline \multirow{2}{*}{ Godrej Industries Ltd } & $9.28 \mathrm{e}-05$ & 0.045376 & 0.865384 & 0.074393 \\
& $(3.39669)$ & $(3.538654)$ & $(35.35983)$ & $(3.19822)$ \\
\hline Hexaware Technologies Ltd & 0.001915 & 0.117858 & 0.554162 & -0.125071 \\
& $(1.298742)$ & $(1.241203)$ & $(1.648717)$ & $(-1.291627)$ \\
\hline Indraprastha Gas Ltd & 0.000318 & 0.232304 & 0.071445 & 0.618927 \\
& $(14.63033)$ & $(5.095968)$ & $(1.861946)$ & $(9.004281)$ \\
\hline \multirow{2}{*}{ Jain Irrigation Systems } & 0.003393 & 0.015343 & 0.580019 & -0.018706 \\
\hline \multirow{2}{*}{ Mcleod Russel India Ltd } & $(0.743701)$ & $(1.875634)$ & $(1.025234)$ & $(-7.363848)$ \\
\hline \multirow{2}{*}{ NMDC Ltd } & 0.00015 & 0.028724 & 0.867958 & 0.050987 \\
& $(2.642025)$ & $(1.809134)$ & $(21.30301)$ & $(2.117404)$ \\
\hline Shriram Transport Fin Co & $1.74 \mathrm{e}-05$ & 0.138112 & 0.84626 & 0.031157 \\
& $(5.727117)$ & $(9.025231)$ & $(80.88347)$ & $(1.116173)$ \\
\hline
\end{tabular}

The results of GJR GRCH test is shown in the above table. The leverage terms in the above table is used to analyse whether the returns are asymmetric. A positive coefficient of the leverage terms shows that the data is asymmetric. From the above table it's clear that all firms except Hexaware Technologies Ltd and Jain Irrigation Systems, stock returns are asymmetric. In this study GJR GARCH is used to understand the effect of the asymmetric scripts and standard GARCH model is used to estimate the effect of symmetric scripts.

To estimate whether the volatility has increased or decreased after the introduction of derivatives a dummy variable is introduced in the conditional variance equation. The dummy variable takes the value ' $O$ ' in the pre derivatives period and ' 1 ' in post derivative period. For the asymmetric scripts GJR GARCH model is used and for symmetric scripts standard GARCH model is used. Initially the calculation is done without controlling the market pervasive factors then the return of nifty is introduced to include market pervasive factors.

Table 6: Effect of Derivatives on the Volatility of the Underlying Stock without considering the market pervasive factors (Source: Authors' computation)

\begin{tabular}{|c|c|c|c|c|}
\hline Name of the Stock & Constant & ARCH & GARCH & Dummy \\
\hline \multirow{2}{*}{ Adani Enterprises Limited } & 0.003387 & 0.159312 & -0.024564 & -0.002634 \\
& $(64.0366)$ & $(2.664867)$ & $(-27.25381)$ & $(-41.69495)$ \\
\hline \multirow{2}{*}{ Apollo Tyres Ltd } & 0.000145 & 0.020495 & 0.79923 & $-4.77 \mathrm{e}-05$ \\
& $(4.30695)$ & $(1.545564)$ & $(21.7316)$ & $(-3.276923)$ \\
\hline \multirow{2}{*}{ Exide Industries Ltd } & 0.0000592 & 0.074676 & 0.818832 & -0.0000142 \\
& $(3.244907)$ & $(3.09493)$ & $(21.56001)$ & $(-1.750911)$ \\
\hline \multirow{2}{*}{ Godrej Industries Ltd } & 0.0000928 & 0.045376 & 0.865384 & -0.0000504 \\
& $(3.39669)$ & $(3.538654)$ & $(35.35983)$ & $(-2.710073)$ \\
\hline \multirow{2}{*}{ Hexaware Technologies Ltd } & 0.001993 & -0.006696 & 0.403251 & 0.000531 \\
& $(0.757792)$ & $(-126.4043)$ & $(0.511243)$ & $(0.755359)$ \\
\hline \multirow{2}{*}{ Indraprastha Gas Ltd } & 0.000318 & 0.232304 & 0.071445 & -0.0000804 \\
& $(14.63033)$ & $(5.095968)$ & $(1.861946)$ & $(-4.156169)$ \\
\hline
\end{tabular}


Dr. Dhanya Alex, Dr. Roshna Varghese

Derivative Trading and Spot Market Volatility: Evidence from Indian Market

\begin{tabular}{|c|c|c|c|c|}
\hline Jain Irrigation Systems & $\begin{array}{c}0.0000513 \\
(4.163448)\end{array}$ & $\begin{array}{c}-0.002881 \\
(-6.606537)\end{array}$ & $\begin{array}{c}0.9568 \\
(83.59746)\end{array}$ & $\begin{array}{c}0.000275 \\
(3.723491)\end{array}$ \\
\hline Mcleod Russel India Ltd & $\begin{array}{c}0.00015 \\
(2.642025)\end{array}$ & $\begin{array}{c}0.028724 \\
(1.809134)\end{array}$ & $\begin{array}{c}0.867958 \\
(21.30301)\end{array}$ & $\begin{array}{c}-0.000109 \\
(-2.686567)\end{array}$ \\
\hline NMDC Ltd & 0.0000174 & 0.138112 & 0.84626 & -0.00000379 \\
& $(5.727117)$ & $(9.025231)$ & $(80.88347)$ & $(-0.990432)$ \\
\hline Shriram Transport Fin Co & 0.000307 & 0.164473 & 0.272245 & -0.0000174 \\
$(6.337862)$ & $(3.234119)$ & $(2.650441)$ & $(-0.744078)$ \\
\hline
\end{tabular}

The value of dummy variable is considered to analyse the impact of introduction of derivatives, positive coefficients indicate that the volatility has increased and negative coefficients indicate decrease in volatility. From the results presented it's clear that the volatilities of all except Hexaware Technologies Ltd and Jain Irrigation Systems decreased.

Table 7: Effect of Derivatives on the Volatility of the Underlying Stock after considering the market pervasive factors (Source: Authors' computation)

\begin{tabular}{|c|c|c|c|c|c|}
\hline Name of the Stock & Nifty & Constant & ARCH & GARCH & Dummy \\
\hline Adani Enterprises Limited & 0.852689 & $\begin{array}{c}0.01858 \\
(40.70954)\end{array}$ & $\begin{array}{c}0.188469 \\
(3.137155)\end{array}$ & $\begin{array}{c}-0.02389 \\
(-1.273707)\end{array}$ & $\begin{array}{c}-0.001309 \\
(-37.47101)\end{array}$ \\
\hline Apollo Tyres Ltd & 0.770584 & $\begin{array}{c}0.00013 \\
(3.49795)\end{array}$ & $\begin{array}{c}0.022171 \\
(1.391628)\end{array}$ & $\begin{array}{c}0.789189 \\
(16.79576)\end{array}$ & $\begin{array}{c}-4.38 e-05 \\
(-2.998053)\end{array}$ \\
\hline Exide Industries Ltd & -0.008637 & $\begin{array}{c}0.0000591 \\
(3.185759)\end{array}$ & $\begin{array}{c}0.074874 \\
(3.105505)\end{array}$ & $\begin{array}{c}0.819157 \\
(21.28758)\end{array}$ & $\begin{array}{c}-0.0000142 \\
(-1.735585)\end{array}$ \\
\hline Godrej Industries Ltd & 1.18201 & $\begin{array}{c}-0.00000689 \\
(-6.196118)\end{array}$ & $\begin{array}{c}-0.007137 \\
(-35.90861)\end{array}$ & $\begin{array}{c}0.998996 \\
(3506.619)\end{array}$ & $\begin{array}{c}0.00000567 \\
(6.167316)\end{array}$ \\
\hline Hexaware Technologies Ltd & 0.188723 & $\begin{array}{c}0.001784 \\
(1.312453)\end{array}$ & $\begin{array}{c}0.121871 \\
(1.098549)\end{array}$ & $\begin{array}{c}0.534876 \\
(1.535907)\end{array}$ & $\begin{array}{c}0.000287 \\
(1.303064)\end{array}$ \\
\hline Indraprastha Gas Ltd & 0.030528 & $\begin{array}{c}0.000315 \\
(14.32414)\end{array}$ & $\begin{array}{c}0.22981 \\
(4.842362)\end{array}$ & $\begin{array}{c}0.077376 \\
(1.883301)\end{array}$ & $\begin{array}{c}-0.000079 \\
(-4.132399)\end{array}$ \\
\hline Jain Irrigation Systems & 0.597929 & $\begin{array}{c}0.003237 \\
(0.90319)\end{array}$ & $\begin{array}{c}-0.003236 \\
(-77.20411)\end{array}$ & $\begin{array}{c}0.577392 \\
(1.228505)\end{array}$ & $\begin{array}{c}0.000231 \\
(0.537899)\end{array}$ \\
\hline Mcleod Russel India Ltd & 0.862044 & $\begin{array}{c}0.001023 \\
(4.327838)\end{array}$ & $\begin{array}{c}0.097578 \\
(2.696451)\end{array}$ & $\begin{array}{c}0.127751 \\
(0.734901)\end{array}$ & $\begin{array}{c}-0.000709 \\
(-4.200816)\end{array}$ \\
\hline Nhriram Transport Fin Co & -0.017043 & $\begin{array}{c}0.000307 \\
(6.218456)\end{array}$ & $\begin{array}{c}0.162444 \\
(3.223196)\end{array}$ & $\begin{array}{c}0.274081 \\
(2.637577)\end{array}$ & $\begin{array}{c}-0.0000168 \\
(-0.714058)\end{array}$ \\
\hline
\end{tabular}

To understand the effect of market pervasive factors the coefficients of dummy variables in above two tables are compared. After looking at the above two tables it's clear that the difference in dummy variable is negligible except in the case of Godrej Industries Ltd. In case of Godrej Industries Ltd the volatility has increased after controlling the market wide conditions. In a whole we can conclude that the effect of introduction derivatives reduced the volatility of the underlying stocks.

Now GJR GARCH model is used to model the pre derivative and post derivative period returns. This is done to compare the different coefficients like asymmetric nature, effect of recent news and old news. 
Dr. Dhanya Alex, Dr. Roshna Varghese

Derivative Trading and Spot Market Volatility: Evidence from Indian Market

Table 8 Pre Derivative Period Analysis (Source: Authors' computation)

\begin{tabular}{|c|c|c|c|c|}
\hline Name of the Stock & Constant & ARCH & GARCH & Leverage \\
\hline \multirow{2}{*}{ Adani Enterprises Limited } & 0.001411 & 0.022175 & -0.029551 & 0.58691 \\
& $(0.899198)$ & $(0.198525)$ & $(-0.264649)$ & $(1.2781)$ \\
\hline \multirow{2}{*}{ Apollo Tyres Ltd } & 0.000159 & 0.014115 & 0.17839 & $7.73 e-01$ \\
& $(3.580041)$ & $(0.809816)$ & $(3.389484)$ & $(17.19488)$ \\
\hline \multirow{2}{*}{ Exide Industries Ltd } & 0.0000286 & 0.090667 & 0.03759 & 0.860623 \\
& $(1.976952)$ & $(2.980027)$ & $(0.729312)$ & $(25.94257)$ \\
\hline \multirow{2}{*}{ Godrej Industries Ltd } & 0.0000694 & 0.093623 & 0.107582 & 0.836416 \\
& $(3.188329)$ & $(4.154984)$ & $(2.573885)$ & $(31.92443)$ \\
\hline \multirow{2}{*}{ Hexaware Technologies Ltd } & 0.0000162 & -0.003093 & 0.041208 & 0.98334 \\
& $(3.165875)$ & $(-2.824903)$ & $(4.408895)$ & $(326.0652)$ \\
\hline \multirow{2}{*}{ Indraprastha Gas Ltd } & 0.000198 & 0.373138 & -0.350429 & 0.399745 \\
& $(4.35502)$ & $(4.683318)$ & $(-4.063001)$ & $(3.259553)$ \\
\hline \multirow{2}{*}{ Jain Irrigation Systems } & 0.0000828 & 0.055388 & 0.142533 & 0.805025 \\
& $(2.390627)$ & $(1.88217)$ & $(2.892687)$ & $(15.97991)$ \\
\hline \multirow{2}{*}{ Mcleod Russel India Ltd } & 0.000788 & -0.014008 & 0.151843 & 0.508858 \\
& $(1.620075)$ & $(-0.39901)$ & $(1.432098)$ & $(1.690289)$ \\
\hline \multirow{2}{*}{ NMDC Ltd } & 0.00000809 & 0.221119 & 0.017658 & 0.821749 \\
& $(2.716723)$ & $(8.618058)$ & $(0.319949)$ & $(65.08233)$ \\
\hline \multirow{2}{*}{ Shriram Transport Fin Co } & 0.000311 & 0.135163 & 0.270388 & 0.249815 \\
& $(5.165155)$ & $(1.79293)$ & $(3.071024)$ & $(1.86294)$ \\
\hline
\end{tabular}

Table 9: Post Derivative Period Analysis (Source: Author's computation)

\begin{tabular}{|c|c|c|c|c|}
\hline Name of the Stock & Constant & ARCH & GARCH & Leverage \\
\hline \multirow{2}{*}{ Adani Enterprises Limited } & 0.000203 & 0.516984 & 0.887041 & 0.224701 \\
& $(10.5344)$ & $(4.321113)$ & $(5.015182)$ & $(6.547536)$ \\
\hline \multirow{2}{*}{ Apollo Tyres Ltd } & 0.000100 & 0.028944 & 0.093942 & 0.798984 \\
& $(1.895949)$ & $(1.207651)$ & $(1.834794)$ & $(9.878277)$ \\
\hline \multirow{2}{*}{ Exide Industries Ltd } & 0.000321 & -0.032289 & 0.260554 & 0.211873 \\
& $(4.466421)$ & $(-0.525213)$ & $(2.34212)$ & $(1.183734)$ \\
\hline \multirow{2}{*}{ Godrej Industries Ltd } & 0.000094 & -0.092969 & 0.091554 & 0.892248 \\
& $(2.692423)$ & $(-4.178533)$ & $(3.464427)$ & $(16.43776)$ \\
\hline \multirow{2}{*}{ Hexaware Technologies Ltd } & 0.000035 & 0.682632 & -0.687912 & 0.819834 \\
& $(2.735031)$ & $(26.3624)$ & $(-26.14388)$ & $(43.91858)$ \\
\hline \multirow{2}{*}{ Indraprastha Gas Ltd } & 0.000237 & 0.059320 & 1.394057 & 0.078355 \\
& $(12.07297)$ & $(1.12058)$ & $(10.48985)$ & $(1.769246)$ \\
\hline \multirow{2}{*}{ Jain Irrigation Systems } & 0.003890 & 0.033649 & -0.037371 & 0.597827 \\
& $(0.774645)$ & $(0.071563)$ & $(-0.079473)$ & $(1.150916)$ \\
\hline \multirow{2}{*}{ Mcleod Russel India Ltd } & 0.000083 & 0.058197 & 0.081526 & 0.751448 \\
& $(1.510712)$ & $(1.500276)$ & $(1.157899)$ & $(5.582003)$ \\
\hline \multirow{2}{*}{ NMDC Ltd } & 0.000100 & 0.022948 & 0.263876 & 0.627218 \\
& $(2.954128)$ & $(0.634466)$ & $(3.260138)$ & $(6.667269)$ \\
\hline \multirow{2}{*}{ Shriram Transport Fin Co } & 0.000296 & 0.212957 & 0.027965 & 0.257081 \\
& $(3.062141)$ & $(2.770574)$ & $(0.289783)$ & $(1.407193)$ \\
\hline
\end{tabular}

In the above tables (Table $8 \& 9$ ) the ARCH term stands for the effect of recent news on the returns and GARCH term stands for the effect of old news. From the table it's clear that after the introduction derivatives the $A R C H$ of five scripts have increased showing the increased effect of recent news. At the 


\section{Dr. Dhanya Alex, Dr. Roshna Varghese \\ Derivative Trading and Spot Market Volatility: Evidence from Indian Market}

same time ARCH of five got reduced showing reduced effect of recent news. The GARCH term of seven scripts in the post derivative period has increased showing an increased effect of old news.

By looking at the leverage effect coefficient we could understand the asymmetric nature of the stocks. A positive value corresponds to an asymmetric nature where asymmetry means that the effect of bad news on a stock will be always greater than the effect of good news on the stock. By looking at the above two tables we can see that before introduction of derivatives two stocks namely Adani Enterprises Limited and Indraprastha Gas Ltd were symmetric and rest of the stocks were asymmetric. After the introduction of derivatives the above said two stocks have asymmetric nature, but two scripts, Hexaware technologies Ltd and Jain Irrigation Systems show symmetric nature and all the others are asymmetry. Thus it can be concluded that most of the stocks have an asymmetric nature irrespective of the introduction of derivatives.

The study has the following limitations. (1) Closing price considered are not adjusted for the effects of dividends and splits. (2) Only the effects of derivatives launched in a year are considered. (3)Volume of derivative trading is less for these stocks.

\section{CONCLUSION}

The aim of the current study was to estimate the effect of introduction of individual stock derivatives on underlying stocks. To do this GARCH family models were used. For the study, ten stocks on which derivatives were introduced in the year 2010 were considered. Closing prices of these stocks for 500 days before and after the introduction of derivatives were used.

Initially logarithmic returns of the closing prices of the ten companies considered were calculated. In order to find out whether the series are stationary, Dickey-Fuller test and Phillips-Perron test were used. Results of these tests proved that the series are stationary or are free of trends. Further analysis was done using skewness, kurtosis, Jarque-Bera statistics, ARCH test coefficients etc. for the pre derivative period, post derivative period and full period. Skewness for all the companies were found to be greater than zero, kurtosis were in excess of three, JB test statistics showed that assumption of normality is violated and in most of the cases $A R C H$ test coefficients suggested that there is ARCH effect. All these results confirm that GARCH family models could be employed.

Then GJR GARCH model was used to find out the asymmetric nature of the stock returns. From the results it is clear that most of the companies showed asymmetric nature, i.e. effect of bad news is greater than the effect of good news. Then to find out whether the volatility has changed, a dummy variable is added in the variance equation of GJR GARCH model in case of asymmetric stocks and dummy variable is added in the variance equation of standard GARCH model in case of symmetric stocks. For most of the companies coefficients of dummy variable was found to be less than zero concluding that the volatility has decreased. To find the effect of market pervasive factors on volatility, return of nifty was used in the mean equation. Comparison of the two results showed that effect of market pervasive factors was insignificant. Finally GJR GARCH model was employed on the pre derivative period and post derivative period of all the stocks considered. Output of this showed that effect of old and recent news were different for pre and post derivative period. Most of the companies showed asymmetric nature in both the periods.

Result of the current study is in agreement with the studies done earlier in the Indian market that the introduction of derivatives has reduced the volatility of the underlying and the stocks show asymmetric nature. (Abhilash, 2011). Result of the study could be used by the players in the stock market to formulate their tradingstrategies, by regulators of market to put forward surveillance measures, which will make the market more efficient.

\section{About the author:}

Dr Roshna had been a research fellow with fellowship from University Grants Commission (UGC) in Mahatma Gandhi University for four years. She did PhD in the topic Corporate Disclosure by Indian Companies. She joined Rajagiri after working three years at Saintgits Institute of Management. She has presented research papers in various national and international conferences including those of IIMK, IIMC and Indian Academy of Management. Further she has published several articles in refereed national journals. She has two books publication in her credit and has contributed book chapters in many edited books. Dr. Roshna's research specialty is examining the voluntary disclosure in annual reports of companies. She also does work in corporate valuation, microfinance and capital market. Areas of expertise include capital markets, Financial restructuring, corporate finance and investments. 


\section{Dr. Dhanya Alex, Dr. Roshna Varghese \\ Derivative Trading and Spot Market Volatility: Evidence from Indian Market}

Dr. Dhanya Alex has been a Faculty member in the Business Management programmes for more than 12 years. Before joining FISAT Business School, she worked as Assistant Professor in Rajagiri Centre for Business Studies, Kochi and Christ University (erstwhile Christ College) Bangalore. She has been awarded PhD by the Cochin University of Science and Technology on the topic "Corporate Risk Disclosures and Its Impact on Cost of Equity". She has post graduate degrees in Commerce and Business Administration. She has been a Visiting International Scholar at Western Michigan University, USA and Nazareth College, Rochester, New York, USA. Areas of interest include corporate disclosures, firm valuation, security analysis and portfolio management and corporate finance.

\section{REFERENCES}

- Abhilash, S. Nair. (2011). Existence and Extent of the Impact of Introduction of Individual Stock Derivatives Trading on the Volatility of the Underlying. Applied Financial Economics, 21, pp. 563600.

- $\quad$ Agung, Gusti. (2009). Time Series Data Analysis Using Eviews. John Wiley \& Sons

- Alexander, Carol. (2008). Market Risk Analysis Volume II Practical Financial Econometrics. John Wiley \& Sons.

- Antoniou A, Holmes, P. (1993). Futures trading, information and spot price volatility: evidence for the FTSE-100 Stock Index Futures contract using GARCH. Journal of Banking \& Finance, 19, pp117-129.

- Bandivadekar, S, and Ghosh, S. (2003). Derivatives and Volatility on Indian Stock Markets. Reserve Bank of India Occasional Papers, 23, pp. 187-201.

- Bollerslev, T. (1986). Generalised Autoregressive Conditional Heteroskedasticity. Journal of Econometrics, 33, pp. 307-27.

- Bologna, P. and Cavallo, L. (2002) Does the introduction of Stock Index Futures Effectively Reduce Stock Market Volatility? Is the 'Futures Effect' Immediate? Evidence from the Italian stock exchange using GARCH. Applied Financial Economics, 12, pp. 183-92.

- Brooks, Chris. (2008). Introductory Econometrics for Finance. Cambridge University Press.

- Chatrath, Arjun, Sanjay Ramchander and Frank Song. (1995). Does options trading leads to greater cash market volatility? Journal of Futures Markets, 15(7), pp $785-803$.

- Cox, C.C., (1976). Futures Trading and Market Information. Journal of Political Economy, 84, pp. 1215-37.

- Min-Hsien Chiang \& Cheng-Yu Wang. (2002). The Impact of Futures Trading On Spot Index Volatility: Evidence For Taiwan Index Futures. Applied Economics Letters, 9, pp $381-385$.

- Dennis, S.A. and Sim, A.B. (1999). Share Price Volatility with the Introduction of Individual Share Futures on the Sydney Futures Exchange. International Review of Financial Analysis, 8, pp. 153- 163.

- Donald, Cooper, Pamela, Schindler. And JK, Sharma. (2012). Business Research Methods by, McGraw-Hill Companies, Inc.

- Engle, R.F. (1982). Autoregressive Conditional Heteroskedasticity with Estimates of the Variance of United Kingdom Inflation. Econometrica, 50, pp. 987-1007.

- Engle, R.F. (2001). GARCH 101: The Use of ARCH/GARCH Models in Applied Econometrics. Journal of Economic Perspectives, 15, pp 157-168.

- Figlewski, Stephen. (1981). Futures trading and volatility in the GNMA Market. Journal of Finance, 36, pp $445-484$.

- Nath, G.C. (2003). Behaviour of Stock Market Volatility after Derivatives. http://nseindia.com/content/press/nov2003a.pdf.

- Powers, M.J. (1970). Does futures trading reduce price fluctuations in the cash markets? American Economic Review, 60, pp 460 - 464.

- Schwartz, T.V. and Laatsch. (1991). Dynamic efficiency and price leadership in stock index cash and futures markets, Journal of Futures Markets, 11, pp 669 - 683.

- Shenbagaraman, P. (2003). Do Futures and Options Trading increase Stock Market Volatility? NSE Research Initiative, Paper No. 20.

- Stein, J.C. (1987). Information externalities and welfare reducing speculation. Journal of Political Economy, 31, pp 307 - 327.

- Tenmozhi, M. (2002). Futures Trading, Information and Spot Price Volatility of NSE-50 Index Futures Contract. National Stock Exchange Working Paper No. 59, Mumbai.

- Tsay, Ruey S. (2005). Analysis of Financial Time Series, John Wiley \& Sons. 